\title{
BUILDING COALITIONS: Structure
}

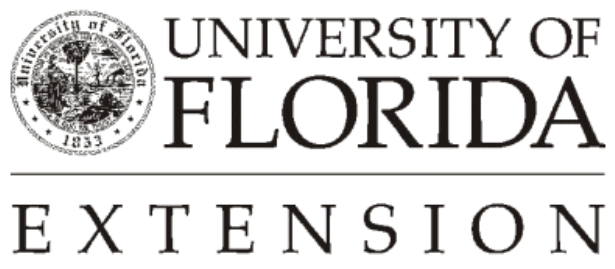

Institute of $\mathbf{F}_{\text {ood and }} \mathbf{A}_{\text {gricultural }} \mathbf{S}_{\text {ciences }}$ 


\section{Construction of a Coalition}

Structure may refer to the form by which the collaboration accomplishes its mission. The people who lead, participate in and eventually implement the activities of interagency initiatives, affect the growth and development of joint efforts.

The coalition is essentially a mechanism for increasing the power or leverage of groups or individuals. The object is to get more out of the coalition than is put into it.

Situations, although difficult or impossible for the individual to overcome alone, can be dealt with simply and rapidly by acquiring the right allies. This is coalition building.

Begin by analyzing the problem: What do you want to achieve? Who can help (or hurt) your efforts? What are the rewards for becoming part of a coalition? What action is needed to meet the objectives?

A coalition should be structured to:

1. Involve all key players.

2. Choose a realistic strategy.

3. Establish a shared vision.

4. Agree to disagree in the process.

5. Make promises that can be kept.

6. Build ownership at all levels.

7. Institutionalize change.

8. Publicize successes.

\section{Who should Initiate a Coalition?}

The initiating organization will experience success in effecting collaboration if it can show the credibility of the employees and their commitment to collaborative efforts. Those who form the coalition must develop a loyalty to the core group that is strong enough to cope with competing pressures from their organizations. 
Obviously, no collaborative experience is identical to any other. The greater the functions complement (as contrasted to being similar) the collaborative venture and the individual members, the greater the likelihood of cooperative action.

\section{Support for the Coalition}

The social and political climate in a neighborhood or community is the first factor likely to influence an interagency initiative.

Bringing key decision makers into the coalition at the beginning gets them interested in the issue. It also helps keep it alive through constant visibility with community leadership and the press. Involving key decision makers gives credibility to the project.

Three fundamental items are needed by coalitions to develop enough political power to influence change--unless, of course one has a lot of money with which to buy access and influence. The key ingredients are information, numbers of people and widespread coordinated activity. Coalitions need information--about what is or ought to be proposed, its implications, the alternatives, the forces on both sides of the issue, and so forth.

Ask policy-making boards locally or statewide to support your coalition efforts. You may want to:

- $\quad$ Obtain agreement on plans.

- Develop awareness of services within agencies within the local community.

- Involve officials in problem-solving.

- $\quad$ Seek advice and evaluation.

- $\quad$ Share planning, implementation, and local support received.

- $\quad$ Ask elected officials to endorse policies and plans.

\section{Who Should Belong to the Coalition?}

Collaboration begins with the selection of resource people who have experience in dealing with the particular issue and understand the common goal. They have the authority and power to influence change and the energy and enthusiasm for keeping the momentum alive.

Initial contacts usually work best if they are between agency administrators. This follows protocol and allows the administrator to delegate the responsibility. It avoids the administrator hearing about the 
contact from someone lower in the agency, becoming suspicious and defensive, and scuttling the effort before it begins or initially putting it on a bad footing.

Broad-based representation--including youth--is critical. Failure to establish mutual goals and objectives is a major reason collaborations fail. Collaboration rests upon the principle that each person has something to offer.

Traits like patience, persistence, initiative, flexibility, risk-taking, empathy, self-assurance and self-realization are critical to working in a collaborative relationship with others.

Begin by determining all the natural allies-- individuals or groups who share the concern and support a similar position. Continue by seeking all types of persons, groups and social structures likely to be affected by the issue or position taken--both affirmatively or negatively. Do not forget to include all potentially interested and civic-minded groups who might stand to gain indirectly by supporting the issue or constituents.

\section{How to Recruit Members}

The first thing one must know to work with another agency is what it is and does. Face-to-face meetings can address the initial unknowns and allow staff from both agencies to get as much detailed information as necessary.

Building upon existing efforts saves time, resources, and creates strong working relationships. Develop a strategy for selling potential members on the idea of organizing a coalition around issues. The organizer must be clear about how the members of other organizations, their public image, their organizational goals, and so on will be enhanced by involvement in the coalition.

One must be prepared to discuss with each potential member organization the following issues:

- The relationship of this coalition to issues or activities already undertaken or contemplated by the organization.

- $\quad$ Evidence that the issue to be pursued by the coalition is best served through a coalition rather than through existing organizational efforts.

- $\quad$ The immediate and long-range consequences for the public government beneficiaries and so forth.

- $\quad$ The specific impact the organization is likely to experience because of the coalition effort and the effect it will have on the coalition.

- $\quad$ The major decisions that must be made about the coalition and its goals. 
- An assessment of the resources (staff, financial, in-kind) available to and necessary for the coalition to function adequately.

If you are not familiar with or have a negative impression of another agency, the first step is to become acquainted. The main objective of an initial contact is to open communication.

Finally, another way of identifying groups is by administering a community information questionnaire. This also gathers data about the political, social, economic and power bases in the district. This information could serve as a starting point for determining the constituencies from which coalition members will be recruited.

\section{Keeping the Momentum Alive}

Formally-organized coalitions have a governing board that establishes policy and generates funds. To maintain credibility, the board's composition should represent all community segments the coalition wishes to embrace.

Once the board is established, a common practice is to form committees to oversee the coalition's projects. Tasks can be allocated among committees that enlist the help of additional participants.

There is yet to be a collaborative effort that functions perfectly, but there is encouragement. Collaboration is a new growth area that is stimulated the more it is practiced.

\section{Formal Versus Informal Coalitions}

Once agencies decide to work together, they also must agree on whether their coalition will be primarily cooperative or collaborative in nature. A collaborative strategy is where the need and intent is to change the way services are designed and delivered throughout the system. In communities not yet ready for collaborative partnerships, initiatives to coordinate existing services offer a reasonable starting point for a change.

Three types of collaborative missions exist: service-oriented, where direct services are provided; system-oriented, where efforts are targeted at improvement of the service delivery systems; and dual mission, which encompasses both service and system initiatives. Service and system collaborations differ radically.

Designed to address immediate needs and to improve tangible services, service collaborations chart more circumscribed, easily-accomplished tasks than those generally undertaken by system collaborations. Feedback is more immediate, gratification quicker, and impact more visible. Conversely, the accomplishments of systems collaborations tend to be longer in process, more abstract and less visible. Thus, evaluation needs to discern carefully among service, system, and dual mission efforts, with attention to their differing challenges, timeliness, processes and outcomes. 


\section{Maintaining the Coalition}

Flexibility is the essential condition of a successful collaboration. No matter how carefully goals are defined at the outset, they are routinely challenged, making goal reassessment an ongoing necessity. Early "fiascos" or "aborted efforts" demand flexibility in responding to failure and the recontouring of collaborative activities. The most effective collaborations appear to be strengthened, not defeated, by disappointments and challenges.

Coalitions need to exist only as long as it is useful to its members. But, when it disintegrates before achieving its goal, it usually has fallen victim to one of these defects:

- $\quad$ Failure to keep members informed about the policies and actions of the organization. Lack of information is a prime reason for believing the coalition has been ineffective and therefore for dropping out. To keep the information flowing, it is often necessary to publish newsletters, set up telephone networks or hold frequent discussion meetings even when no decisions have to be made.

- Lack of interim rewards for members. The failure of a coalition to show some concrete results short of ultimate victory often discourages its members. To provide interim reinforcement, it may be necessary to sponsor social events: boat cruises, hayrides, cocktail parties and picnics. Important public figures, such as local office holders, may be asked to attend these activities to show support for the coalition's goals. Such gatherings are essentially surrogates for more tangible rewards, but may work well as stopgap measures.

- Loss of key leaders. An organization may develop a serious vulnerability if one dominant leader prevents others from sharing power. In a well-structured alliance, the leadership role is diffused so the loss of any one person would not be fatal.

- Serious irreconcilable splits over the coalition's direction. Such splits may suggest the coalition was weak to begin with, perhaps because it lacked requirements for cohesion, such as ideological ties. Splits tend to occur during moments of crisis when two seemingly attractive policy alternatives present themselves, or a frustrating defeat is suffered.

- Change conditions. When circumstances arise that were not present when the coalition was formed, it may be unable to adapt. It perishes because its members recalculate the costs and benefits in light of the new circumstances, and the results encourage defection.

- Delay. Unless a coalition is intended to be permanent, the members expect it to achieve its main objective within a reasonable time. 


\section{Recorded Meetings}

A decision should be made early in the planning to set up a mechanism for sending out notices of meetings and recording and distributing meeting minutes. Keeping meeting minutes is important to communicate key ideas that have been discussed; to document resolutions and record other important actions.

It is not always possible for everyone to attend all the meetings, so minutes should always be sent to the members. Keeping everyone informed about how the coalition is developing will do a great deal to keep communication channels open.

\section{Use of Volunteers}

The greatest pool of unused resources for meeting human service needs is the pool of untapped volunteer time and energy. The Gallup Poll shows that the majority of Americans above the age of 14 are ready and willing to give volunteer time for community service.

Every day volunteers and other social practitioners and people-helpers develop innovative, creative and experimental ways to help their clients. Usually, however, they have no way to document their new practices. They simply exchange them verbally and informally, and many get lost. It is estimated that thousands of inventive social practices are lost each year for lack of a good way to share them.

Organizations using volunteers need to develop methods for bringing these social conventions to light. A cross-agency conference could bring together volunteers in a particular field, such as those working with 16 to 21 year olds. They can share what they have found to be successful in working with this age group. Someone can record each respondent's name and address and his or her successful practice, so it can be used by others. Such a conference is also a good way to begin or strengthen collaboration between agencies, as it demonstrates their interdependence and enriches them both.

\section{Summary}

The people or groups recruited into the coalition, the support for and where this support comes from in the community, and the design form the structure of the coalition. These need to be planned with purpose so the coalition can be a successful venture. 


\section{References}

Hart, Thomas. Building Coalitions for Support of Schools, Oregon School Study Council, Vol. 32, no. 1, September 1988.

Kagan, Sharon L., Ann Marie Rivera and Faith Lamb Parker. Collaborations in Action: Reshaping Services to Young Children and Their Families. Executive Summary, The Bush Center in Child Development and Social Policy, Yale University, January 1991.

Levin, Edward and R.V. Denenberg. Alliances and Coalitions--How to Gain Influence and Power by Working with People. McGraw-Hill Book Co., 1984.

Linking Schools and Community Services, A Practical Guide. Center for Community Education School of Social Work. The State University of New Jersey, Rutgers.

Lippitt, Ronald and Jon Van Till. "Can We Achieve a Collaborative Community? Issues, Imperatives, Potentials," Journal of Voluntary Action, Research, Vol. 10 (July-December 1981) 7-17.

Rodriguez, Esther, Patrick McQuaid and Ruth Rosauer. Community of Purpose: Promoting Collaborations Through State Action. Education Commission of the States, February 1988.

Rossi, Robert J., Kevin J. Gilmartin and Charles W. Dayton. Agencies Working Together, A Guide to Coordination and Planning. Sage Publications.

\section{Authors}

Penne Smith, County Extension Agent, 4-H, CNRD, Chair, Ohio Cooperative Extension Service, The Ohio State University.

Charles H. Bell, Associate Professor, District Specialist, 4-H, Ohio Cooperative Extension Service, The Ohio State University.

C) 1992 The Ohio State University

DECS Ohio Cooperative Extension Senice 
This series on Coalition Building was developed by The Ohio Center For Action on Coalition Development for Family and High Risk Youth, Richard Clark, Ph.D., Director. It has been adapted for County Extension Faculty in Florida to facilitate work with local and regional organizations and groups such as non-profits, cooperatives, county extension associations, and others that might benefit from a plan for working together to achieve support for mutual goals.

This document is FY504, Part 12 of the 16 part series adapted for use in Florida by Elizabeth B. Bolton, Professor, Community Development and Lisa Guion, Assistant Professor, Program Planning and Evaluation; Department of Family, Youth and Community Sciences, Florida Cooperative Extension Service, Institute of Food and Agricultural Sciences, University of Florida, Gainesville, 32611-0310.

Reprinted with permission March, 1997. Revised April, 2002.

The Institute of Food and Agricultural Sciences is an equal opportunity/affirmative action employer authorized to provide research, educational information and other services only to individuals and institutions that function without regard to race, color, sex, age, handicap, or national origin. For information on obtaining other extension publications, contact your county Cooperative Extension Service office.

Florida Cooperative Extension Service/Institute of Food and Agricultural Sciences/University of Florida/Christine Taylor Waddill, Dean 